\title{
Economics, Politics, and Natural Law
}

\author{
Philip J. Harold
}

Contemporary English-language theorists have used the natural law theory of St. Thomas Aquinas as a basis for a theory of moral action. ${ }^{1}$ This paper will show on the contrary that natural law cannot be turned into a moral theory because it includes a politics of the common good, while moral theories deal instead with economic questions which are always divisive. The resolution of economic issues can only take place within a politics that is not understood exclusively in economic terms. First, the differences will be sketched between the two components of practical questions, the economic and the political, and then it will be argued that Aquinas's explication of natural law respects the transcendence of the common good, accommodates pluralism on economic questions, and respects individual dignity vis-à-vis the claims of the community.

\section{Economics and Politics}

According to the classical definition of economic exchange, self-interested parties enter into a contract voluntarily and both benefit from the transaction. ${ }^{2}$ But even according to this model, there must be something deeper than self-interest, and the good of the other person must in some way also be good for me too. After all, if we were not at all interested in benefiting our partner in exchange, we could defraud them and reap an easy benefit. Fraud must of course be prohibited in order for the whole economy to function, and in the long-term this is good for me individually too. Thinking along these lines, the liberal theorists base their political thought on the concept of long-term self-interest. When John Locke, for example, asks why man will part with natural freedom, he answers that it is because "the enjoyment of the property he has in this state is very unsafe, very unsecure. This makes him willing to quit a condition, which, however free, is full of fears and continual dangers." He concludes that "[t]he great and chief end, therefore, of men's uniting into commonwealths, and putting themselves under government, is the preservation of their property." 3 Political unity becomes a kind of

1 E.g. Germain Grisez, Joseph Boyle, and John Finnis, "Practical Principles, Oral Truth, and Ultimate Ends," American Journal of Jurisprudence, 32 (1987), 99-151. Also Cf. John Finnis, Aquinas: Moral, Political, and Legal Theory (Oxford: Oxford University Press, 1998), 79. Finnis admits there that he is constructing a moral theory which does not exist in Aquinas. The best critique of the FinnisGrisez new natural law theory is Russell Hittinger, A Critique of the New Natural Law Theory (Notre Dame, Ind.: University of Notre Dame Press, 1987).

2 "Adam Smith's key insight was that both parties to an exchange can benefit and that, so long as cooperation is strictly voluntary, no exchange will take place unless both parties do benefit." Milton Friedman and Rose Friedman, Free to Choose: A Personal Statement (New York: Houghton Mifflin Harcourt), xv.

3 John Locke, Two Treatises of Government, ed. Peter Laslett (Cambridge: Cambridge University Press, 1988), 350 . 
economic transaction, a "social contract" where individuals realize greater benefits over the long term. Systematic thinking about interests in this way defines the very concept of morality; moral thinking considers how my individual action affects all of society considered as a conceptualizable system of reciprocal actions, as an economy. 4

The problem is that relying on long-term self-interest is an insufficient basis for economy. ${ }^{5}$ A sustainable economy - a Volkswirtschaft and not merely one-off transactions - only works if on some level our neighbor's good is our good, if we identify with the people around us and wish them well. This kind of general identification is enabled by politics, in the widest sense of the word. ${ }^{6}$ A functioning economy is only possible when there is a prior political solidarity.

By focusing on moral and economic questions, liberal theorists often fail to come to terms with the nature of politics and political leadership. Before there can be a question of imagining how it is that I benefit from my connection with the larger political order, that political order must already be in existence. The question of how I am better off as a member of a society cannot be posed in the abstract: I am already socialized as a part of a society; I always already owe a debt of loyalty to the political order that has created me. ${ }^{7}$ The communitarian critique of liberalism runs along these lines. ${ }^{8}$ Before we can run a cost/benefit analysis of our membership in a political order in order to

4 The categorical imperative of Kant is the classic form of this approach.

5 As J.L. Mackie says, "[T]he rational calculation of long-term self-interest is not sufficient in itself (necessarily) to lead men to make mutually beneficial agreements, or once made, to keep them," even when "combined in the Hobbesian solution with a coercive device." J.L. Mackie, Ethics: Inventing Right and Wrong (New York: Penguin, 1990), 119-20, 124.

6 The terms "politics" and "economics" are used here in the sense given by Betrand de Jouvenel: "[E]conomics is concerned with the use of resources on the spot, politics with adding to them." Politics is a "technique for increasing the human energies at our disposal by rallying other men's wills to our cause." Betrand de Jouvenel, Sovereignty: An Inquiry into the Political Good, trans. J.F. Huntington (Indianapolis: Liberty Fund, 1997), 20, 21. The term "economy" as it is used here is also influenced by the work of Jacques Derrida. Cf. e.g. Jacques Derrida, Margins of Philosophy, trans. Alan Bass (Chicago: University of Chicago Press, 1982), 216-19.

7 Considering whether to break out of prison and escape an unjust death sentence, Socrates imagines talking to the laws of Athens, which say to him, "[S]ince you were brought into the world and nurtured and educated by us, can you deny in the first place that you are our child and slave, as your fathers were before you? And if this is true you are not on equal terms with us; nor can you think that you have a right to do to us what we are doing to you." Plato, Crito 50e.

${ }^{8}$ Cf. Michael Sandel, Liberalism and the Limits of Justice (Cambridge: Cambridge University Press, 1982). Rainer Forst refers to the "communitarian fallacy" of Sandel, which denies the impossibility of a deontological level from the fact of the intersubjective constitution of the self. Rainer Forst, Contexts of Justice: Political Philosophy beyond Liberalism and Communitarianism, trans. John M. M. Farrell (Berkeley: University of California Press, 2002), 231. The problem with Forst's Kantian liberalism is the reduction of morality to economic thinking. Morality comes from recognizing that we live in and from an economy, according to Forst: "The central point is only that the 'foundation' of morality is not the concern for one's own good life or even concern for realizing a vision of the good, but rather a concern for others within the space of what is reciprocally and generally owed (which does not exclude the possibility of supererogatory acts)." Rainer Forst, The Right to Justification (New York: Columbia University Press, 2012), 34. This view is responsible for liberalism's inability to deal with the common good, which is irreducible to economy. 
then reaffirm our loyalty to it "rationally," that order and our loyalty to it has to exist in the first place. While the economic question concerns what exactly is to our advantage, the political question concerns who exactly it is that constitutes the "our" in the first place.

The promise of economic benefit is simply unable to produce the kind of loyalty required of a political order. Thinking in terms of advantage, even long-term advantage, will always lead to an impasse: there will always be disagreement on what should be weighed and considered to be cost and benefit, and hence on how the economy should be structured. "So strong is this propensity of mankind to fall into mutual animosities, that where no substantial occasion presents itself, the most frivolous and fanciful distinctions have been sufficient to kindle their unfriendly passions and excite their most violent conflicts," writes James Madison. "But the most common and durable source of factions has been the various and unequal distribution of property." ${ }^{\prime \prime}$ Realistically, these struggles cannot be solved in advance. Thinking about them in the abstract produces no resolution. ${ }^{10}$ As Madison points out, the division of labor produces different classes of people who have different perspectives, and though this is the source of dissention or "faction," it is not something we should ever think we could eliminate. Political questions about how to structure the economy will always be contentious. ${ }^{11}$

It is tempting to define politics itself as conflict over "who gets what, when, and how." 12 But politics is not originally about conflict, but rather the creation and maintenance of the social bond. Here one must look beyond economic policies, always rife with disagreement, to rhetoric.

"We are all Americans." "We must unite together beyond partisan differences." This way of speaking is outside of mimetic competition. It includes everyone. But it is also basically meaningless: there is no specific content to it, and nothing follows from it. It is therefore easy to dismiss as rhetorical flourishes, ornaments merely for effect or propaganda. Hard-headed positivist social scientists usually do think of it as a tool for pushing a certain agenda. Undoubtedly manipulation occurs all the time: "We are all Americans, so we need to reject those who would oppose the proposed legislation." "We must unite together beyond partisan differences, and this means advancing this particular agenda." But as soon as a political statement has meaning, it is taking a

${ }^{9}$ Federalist \#10, available at http://www.constitution.org/fed/federa10.htm (Accessed 10/3/2012).

10 For example, we could try to just applying the principle of the market - free exchange - when fashioning a democratic political system in which everyone an equal voice and the system most people freely choose wins out. But of course unless everyone agrees unanimously there are going to be some people who will be forced to go along with what everyone else chooses, and even more importantly the disproportionate suffering of the minority may not count as suffering at all, undermining completely the claims we might make about this system being a result of free choice and redounding to everyone's benefit.

11 This is the case even when one adopts the posture of giving a neutral description of the social bond, which as Patrick Riordan suggests, must of necessity always also be advocacy. Patrick Riordan, $A$ Politics of the Common Good (Dublin: Institute of Public Administration, 1996), 102.

12 Harold D. Lasswell, Politics; Who Gets What, When, How (Cleveland: Meridian, 1958). 
stand on the way the economy should be organized and is thus locked in a cycle of conflict, since there will always be those who see things differently.

In order for there to even be political conflict there first has to be a political order which includes the very parties who are fighting. However much we disagree, we do agree that we belong to a country and we wish what is good for our country. Our fates are intertwined together in a common order, the nature of which cannot be explained in terms of raw economic meaning, i.e. who gets what, when, and how, since that is always contested. Nuts-and-bolts policy questions are naturally extremely important, but being inherently divisive one set of answers to them simply cannot form the basis for a political order. Such a foundation is instead expressed by and evoked through symbolism, such as the strictly meaningless phrases which do nothing but recognize a community of responsibility between the parties, the very possibility of communicating and sharing meaning, without yet having any specific economic meaning.

Symbols that express and inspire a patriotic love of country do not mean anything specific, but are more important than they appear in a positivistic worldview. The political art involves building up a community of mutual responsibility and trust, and this involves the creation of a symbolic language which can express it. Two-and-a-half centuries ago the symbols "George Washington," "Bill of Rights," "Bald Eagle," "Stars and Stripes," and "Fourth of July" did not exist, and neither did the United States of America. There cannot be one without the other; creating a political order entails creating the symbolism to express and evoke the whole and its governing principles, e.g. justice, liberty, equality under the law.

Thinking about the political order as an economy leads us inevitably to downgrade this symbolic language and these general principles, considering them to be propaganda or ideology. ${ }^{13}$ This is not to say that we should never flesh out what e.g. liberty and equality mean concretely, but rather that we should not mistake our ideas for the principles themselves. The common good transcends our ideas and reactions, and cannot be enlisted in the struggle between different economic interests.

In a remarkable essay on ancient Chinese political thought, J.G.A. Pocock has brought out a tension in Confucian political theory, which saw society as properly governed by a code of rituals. Participating in ritual is like being a part of a dance there is an order and harmony to a dance without it meaning something as speech does. Without ritual government must rule by decree, using words which have meaning and are backed up by specific punishments. And "[w]here there are words there will be disagreement; where there are categories there will be opposition." 14 But it would be foolish to oppose a "government by ritual" to a "government of words"; both are necessary and unable to be contrasted and played off of one another as if they were competitors in providing the principle of rule. To think this way is already to think in terms of

13 Lasswell does both, analyzing symbolism for example exclusively in terms of propaganda, i.e. as a mechanism used by elites to control the masses. He does have one brief mention of "ideology" that would not be propaganda, and his turn of phrase is interesting: "Happy indeed is that nation that has no thought of itself." Lasswell, 31.

14 J.G.A. Pocock, Politics, Language, and Time (Chicago: University of Chicago Press, 1971), 58. 
economy, where what matters is to get the right moral principles, so as to apply them in shaping society. Pocock in fact identifies two heresies to the traditional Confucian view which do exactly this: the anarchist Taoists who drew the conclusion that, since the communal order cannot be expressed in words, words and government must be bad; and the totalitarian Legalists who drew the Hobbesian conclusion that the will of the ruler must determine the meaning of words.

To think of politics in terms of economy means to think in terms of contrary principles, as if politics were a problem that could be solved in advance by picking the right principle and then enforcing it. But the recognition of the symbolism essential to creation of political order does not offer us just another principle having moral and political content which would be in competition with other principles. Rather, there is something here that is outside of competition, a solidarity that includes everyone in the entire society. An awareness of this brings us to the limits of economic thought. Economic and moral thinking is necessary, but it is not exclusive. It is limited, but it is not in competition with political thought. Economics is limited by politics and not by force, as that would be to form a new economy between two opposed principles.

We might think here of the difference between having a merely economic relationship with my butcher, which would change when a competitor offers a lower price, and a relationship of friendship. An economic relationship depends upon tallying the costs and benefits one is accruing, but imposing this framework upon a friendship would be to destroy it. The two types of relationship are not in competition with each other, it is not an either-or. Friendship transcends an economic relationship. While it is outside of economy, it is not opposed to it as its contrary, as if the more friendship there was, the less of an economic relationship there would be. In fact the reverse is true; the more people are friends with each other the more potential there is for a well-functioning economy from the social trust built up as a result. 15

\section{The Common Good Orientation of Law}

An exclusively economic understanding of the basis of the social order is inevitably zero-sum. When principles and symbols are contrasted with each other in a system where the meaning comes from the play of differences, asserting the value of one thing means diminishing or excluding its competition. Persecution is inevitable for an exclusively economic perspective on politics: if ideology is at the heart of the social order, it is in competition and conflict with rival ideologies which it must combat and persecute in order to maintain itself. If we are bound together in society through an ideology or a set of "ultimate ends" we supposedly choose, then a threat to those principles is a threat to our whole social order, something of course we could never approach with rational

15 Cf. Francis Fukuyama, Trust: The Social Virtues and the Creation of Prosperity (New York: The Free Press, 1995). 
detachment. ${ }^{16}$ To make the social bond ideological is to succumb to irrationality. "We live as did the ancients when their world was not yet disenchanted of its gods and demons, only we live in a different sense," says Max Weber. "Fate, and certainly not 'science,' holds sway over these gods and their struggles."17

The alternative is a political understanding that is not exclusively economic, making room for the symbolic in reflecting and evoking social order. The foundation of the social order will be in this case the common good. According to St. Thomas Aquinas, law is oriented towards the common good. The key to understanding the nature of law for Aquinas is neither force nor even its purpose in making men good; as Jean Porter states, Aquinas "emphasizes the character of law as a norm of reason that is oriented toward the common good.... Aquinas is the first scholastic to link legislative authority explicitly to the common good." 18 While ideologies provide justifications for the use of force and for persecutions, the common good is unable to be captured in an intellectual frame. It does not form an economic program but a political symbolism, evocative and unable to be exhausted in a system of thought.

In Question 90 of the Summa, "On the Essence of Law," Aquinas asks four questions, beginning with "Whether law is something pertaining to reason?" The weight of this question is easy to feel in contemporary times; we cannot automatically assume that the laws passed by regimes today for example have to do with reason. We might say with Marx that law is a reflection and a tool of the domination of the elites over the lower classes. We might agree with Burke and say that law is an accretion of the past which should be built up over centuries of tradition and not rationally designed. Or we could say with Adam Smith that the laws of competitive desire and self-interest should regulate human behavior in order to produce good results without the use of reason. According to Aquinas of course law does pertain to reason. Law is neither the mere whim of the ruler nor an unconscious or unintended process. Human beings can have awareness of their end; animals do not and so lack reason. Law is consciously shaped to direct men towards this end, so law gains its rationality from this end. This end is called the "common good."

Aquinas defines "common good" narrowly, however. He rejects the view, for instance, that law is directed to the good of all and to the private good of an individual. Law in its proper sense is only a matter of politics, and the administration of lowerlevel communities, even though they may further the common good in their own way, do not rise to the level of constituting a "common good." The term is reserved for the entire political order; it cannot be said even of large social groupings with leaders who make decisions for the whole that they have a common good, nor is there strictly speak-

16 In the case of American foreign policy this is masterfully illustrated by Christopher Layne, The Peace of Illusions: American Grand Strategy from 1940 to the Present (Ithaca: Cornell University Press, 2006), 118-133.

17 Max Weber, "Science as a Vocation," in From Max Weber: Essays in Sociology, trans. and ed. H.H. Gerth and C. Wright Mills (New York: Oxford University Press, 1946), 148.

18 Jean Porter, "The Common Good in Thomas Aquinas," in Dennis P. McCann and Patrick D. Miller, In Search of the Common Good (New York: T \& T Clark, 2005), 109. 
ing a common good of a family, a corporation, or a union, but only of the allencompassing political unit. The common good is common and not restricted to the good of certain types of people, certain families or voluntary associations.

Et ideo omnis lex ad bonum commune ordinatur - law is "ordained" to the common good. Law does not produce the common good, but the reverse; it is the common good which is responsible for the good order that is present in laws. We produce laws as a result of lawmaking, like building a house results in a house. But laws are not the means we utilize to produce an end result, a system of relations that functions smoothly, that cannot be called the "common good" precisely because the common good is not a product. We do not manufacture it but rather are oriented by it. It is not technical knowledge that we have, but a dynamic whole of which we form a part: we do not possess the key to the common good, rather it has us. We are oriented towards it, but we did not create it nor can we possess it.

The common good is the end to which human rationality is directed when fashioning laws. Jean Porter has pointed to a fundamental paradox here in Aquinas's work. On the one hand, Aquinas often refers to the common good, and it plays a central role in his understanding of politics, public authority, and law. On the other hand, Aquinas does not develop a theory of the common good. ${ }^{19}$ But could we develop such a theory if we decided to, working out for example the rational principles of justice? AngloAmerican political philosophy has been dominated over the last four decades by just such a project, John Rawls's contractual political theory. Is this type of project the fleshing out of political philosophy which Aquinas could have done in principle, but just failed to do? Or instead is it from the outset not a viable proposition?

\section{Two Components of Natural Law}

The natural law is divided into two parts, however: the first common principles, which are the same in all men, and the derived norms which are not valid everywhere. The first principles begin with "good is to be done and evil avoided," with the others being based on that. All societies have the first principles in common; the common element of all common goods, so to speak. They are therefore vague principles like "to live in society," "to shun ignorance," "to avoid offending those with whom one has to live," which are glittering generalities without any specific economic content. This is the common good as political rhetoric presents it. They transcend economy and are truly common, shared by everyone; while we can fail to live up to the natural law and be confused about the proper conclusions to draw from it in concrete situations, we are still always seeking what we think is good under the aspect of goodness. No society would ever be based on the idea that injustice is a good thing; rather, injustice where it exists is always rationalized somehow. Thus it is not the case that some people are on the "side" of the natural law while others oppose it; everyone is already on the "side" of

19 Jean Porter, "Classical Voices: Introduction," in In Search of the Common Good, 92. 
the natural law. ${ }^{20}$ The natural law does not take sides, and we all live under its first principles. Here there is not yet a division of labor, not yet the articulation of society where different people have different functions. But unlike the "original position" of John Rawls, Aquinas does not use this as the basis for creating a moral theory that would define specific economic principles of justice. ${ }^{21} \mathrm{In}$ fact, this is impossible on Aquinas's view, since the specific conclusions that are made from the first principles have to be based on empirical evidence. As conditions change, the effect of actions on the common good changes, and therefore "there is neither the same truth and rectitude among all men" for these "proper or peculiar conclusions of the practical reason." 22 Thus Aquinas is able to explain how the common good of the greater social whole can be foundational for law, unchangeable with all societies respecting it, while at the same time appreciate the historicity and contingency of the common good as manifested in different social orders. A healthy pluralism and pragmatism on economic questions is combined with the necessary transcendence of the good in politics.

For moral theories, by contrast, what matters is how "good" is defined and who has the power to control what it means in practice. These are already economic questions. But for natural law the good transcends any definition of it; what is good cannot be controlled by one group or be the property of a social faction. The common good of a social order includes everyone, or to put it differently, human beings are political animals, and not just economic beings who fight for their survival over and against others. The distinguishing feature of political rhetoric was as we saw its ability to appeal to the common good in this inclusive way, expressing and evoking non-competitive solidarity, viz. friendship and social trust, the basis for any economic order.

This reading of Aquinas enables us to address an issue raised by Matthew Kempshall in his magisterial book The Common Good in Late Medieval Political Thought. He notes that Aquinas is always careful where necessary "to draw back from making each human being completely subordinate to the whole community." $23 \mathrm{He}$ portrays Aquinas as drawing from different models of the common good and therefore able to "modify the language of whole and part" in order to ensure that the individual is not swallowed up by the community. This is, after all, what a focus on virtue might seem to logically lead:

Aquinas's preference for a moral definition of the good of the political community necessarily affects the way in which his political thought has been interpreted. The more moral goodness is stressed, the more the common good of the political community is said to include the individual human being and the more the reservation of a private sphere of activity for the individual effectively disappears. For Aquinas, any virtuous

20 The natural law is in infants and the damned, as Aquinas says in the very first article on the natural law. Summa Theologica I-II q. 94 a. 1.

${ }^{21}$ It is significant that Rawls's approach shifts from the crafting of an economic moral theory (in $A$ Theory of Justice) towards a consideration of political rhetoric (in Political Liberalism).

22 Summa Theologica I-II q. 94 a. 4.

23 M.S. Kempshall, The Common Good in Late Medieval Political Thought (Oxford: Clarendon Press, 1999), 129. 
action, even if it ostensibly affects only the person who performs it, still affects 'another person' in the sense of the whole community of which that individual constitutes a part. ${ }^{24}$

Everything we do or do not do, after all, ultimately affects everyone else. ${ }^{25}$ Our actions have consequences that ripple out far beyond what we intend. When economic thinking considers virtue, it can easily become stifling. The response of liberal theorists is to block off the private space of individual freedom. The mark of a free, liberal order are individual rights limiting government and granting people the ability to live according to their whims in certain matters. The fact that the unintended consequences for others of our actions and omissions are not entirely knowable, as well as the fact that any standard we would apply to judge them would be disputed, justifies us throwing up our hands and ceasing to speak as if the common good were any better than individual goods. ${ }^{26}$

This "solution" is one-sided. It falls into error when the idea of the priority of "the right" and a pluralism of values is taken to deny the very idea of "common good." The liberalism that makes this move reveals itself to be trapped in economic thinking. It takes the current political order for granted, its questioning never leaves the horizon of economy, and it views politics in economic terms, i.e. as something that would limit or shape the functioning of economy by force, opposing it as a contrary. But the relationship of politics and economics, the primary and the special principles of practical reason, is rather non-competitive. Together the two do not form another economy. As Kempshall brings out, and we have explained here in terms of the difference between economics and politics, Aquinas's preferred conceptualization of the common good is the duplex ordo, the double ordering of an internal good or formal cause, and a dynamic external good or final cause. The internal, economic ordering is better named the "common benefit," and it might be better, greater, more superior than the individual

24 Kempshall, 128.

25 Here one thinks of Wickard v. Filburn, a famous United States Supreme Court case which gave an expansive reading to the federal government's power to regulate interstate commerce: the defendant was a farmer who grew wheat in excess of the federal allotment and had to pay the penalty for excess production even though he did not sell it, with the rationale being that otherwise he would have to purchase the extra wheat he needed for his animals, affecting the demand for the commodity, its price, and ultimately commerce between the states.

26 E.g. Isaiah Berlin, Liberty, ed. Henry Hardy (Oxford: Oxford University Press, 2002). 
good, according to Aquinas, but it is not "more perfect." 27 Though political prudence considers all actions, all the virtues are covered under the natural law, and the common good is the same as the individual good; however, the community does not end up stifling the individual because this political level must be an appeal to human freedom. There is political order only where there is free assent. The greater the virtue, the greater the solidarity and the more a political order is made possible, but this cannot be accomplished through force. In economy the individual good can be placed above the common benefit as necessary, and in politics the individual can never be subsumed by the community, as the appeal is always to individual freedom in creating the social bond.

27 Kempshall, 100-1, 115. 